\title{
Gene structures, biochemical characterization and distribution of rat melatonin receptors
}

\author{
Hirotaka Ishii $\cdot$ Nobuyuki Tanaka \\ Momoko Kobayashi · Masakatsu Kato • \\ Yasuo Sakuma
}

Received: 1 June 2008 / Accepted: 10 October 2008/Published online: 6 December 2008

(C) The Physiological Society of Japan and Springer 2008

\begin{abstract}
G-protein coupled receptors for the pineal hormone melatonin have been partially cloned from rats. However, insufficient information about their cDNA sequences has hindered studies of their distribution and physiological responses to melatonin using rats as an animal model. We have cloned cDNAs of two rat membrane melatonin receptor subtypes, melatonin receptor 1a (MT1) and melatonin receptor $1 \mathrm{~b}$ (MT2), using a rapid amplification of cDNA end (RACE) method. The rat MT1 and MT2 cDNAs encode proteins of 353 and 364 amino acids, respectively, and show 78-93\% identities with the human and mouse counterparts. Stable expression of either rat MT1 or MT2 in NIH3T3 cells resulted in high affinity 2$\left[{ }^{125} \mathrm{I}\right]$-iodomelatonin $\left({ }^{125} \mathrm{I}-\mathrm{Mel}\right)$ binding $\left(K_{\mathrm{d}}=73.2 \pm 9.0\right.$ and $73.7 \pm 2.9 \mathrm{pM}$, respectively), and exhibited a similar rank order of inhibition of specific ${ }^{125} \mathrm{I}-\mathrm{Mel}$ binding by five ligands (2-iodomelatonin $>$ melatonin $>6$-hydroxymelatonin $>$ luzindole $>N$-acetyl-5-hydroxytryptamine). RTPCR analysis showed that MT1 is highly expressed in the hypothalamus, lung, kidney, adrenal gland, stomach, and ovary, while MT2 is highly expressed in the hippocampus, kidney, and ovary. We also performed multi-cell RT-PCR to examine the expression of mRNAs encoding MT1 and MT2 in adult GnRH neurons. MT1 was weakly expressed in male GnRH neurons, and was less expressed in the female neurons. MT2 expression was undetectable in
\end{abstract}

Electronic supplementary material The online version of this article (doi:10.1007/s12576-008-0003-9) contains supplementary material, which is available to authorized users.

H. Ishii $(\bowtie) \cdot$ N. Tanaka $\cdot$ M. Kobayashi $\cdot$ M. Kato ·

Y. Sakuma

Department of Physiology, Nippon Medical School,

1-1-5 Sendagi, Bunkyo-ku, Tokyo 113-8602, Japan

e-mail: hirotaka@nms.ac.jp
GnRH neurons from either sex. This study delineates the gene structures, fundamental properties, and distribution of both rat melatonin receptor subtypes, and may offer opportunities to assess the physiological significance of melatonin in rats.

Keywords Melatonin - Melatonin receptors · GnRH neuron

$\begin{array}{ll}\text { Abbreviations } \\ { }^{125} \text { I-Mel } & \text { 2-[ }{ }^{125} \text { I]-Iodomelatonin } \\ \text { DMSO } & \text { Dimethyl sulfoxide } \\ \text { EGFP } & \text { Enhanced green fluorescent protein } \\ \text { GABA } & \gamma \text {-Aminobutyric acid } \\ \text { GnRH } & \text { Gonadotropin-releasing hormone } \\ \text { I-Mel } & \text { 2-Iodomelatonin } \\ \text { mGAPDH } & \text { Mouse glyceraldehyde-3-phosphate } \\ & \text { dehydrogenase } \\ \text { MT1 } & \text { Melatonin receptor 1a } \\ \text { MT2 } & \text { Melatonin receptor 1b } \\ \text { NAS } & N \text {-Acetyl-5-hydroxytryptamine } \\ \text { ORF } & \text { Open reading frame } \\ \text { PT } & \text { Pituitary pars tuberalis } \\ \text { RACE } & \text { Rapid amplification of cDNA end } \\ \text { SCN } & \text { Suprachiasmatic nucleus } \\ \text { UTR } & \text { Untranslated region }\end{array}$

\section{Introduction}

The hormone melatonin is nocturnally synthesized and released by the pineal gland, providing a neurochemical cue of day/night cycles. Melatonin regulates a variety of physiological functions, including circadian rhythms, 
sleep-wake cycles, and reproduction [1]. Melatonin functions via specific high-affinity G-protein coupled membrane receptors, of which there are two receptor subtypes in mammals: melatonin receptor 1a (MT1) and melatonin receptor $1 \mathrm{~b}$ (MT2) $[2,3]$.

Although cDNAs of two melatonin receptors have been cloned in humans and mice [4-7], only partial cDNA sequences have been identified in rats $[4,8,9]$. As a result, the paucity of information about complete open reading frames (ORFs), and $5^{\prime}$ - and $3^{\prime}$-untranslated regions (UTRs) of rat MT1 and MT2 has hindered investigation of melatonin receptors in rats. In the post-genomic era, the ORF regions of rat membrane melatonin receptors can be deduced from the rat genome. Recently, pharmacological properties of the receptors were characterized using genomically identified ORF sequences [10]. However, genomically identified sequences lack information about UTRs that contain the signal motifs involved in posttranscriptional regulation and mRNA decay [11-13].

This study was carried out to characterize the fundamental properties of rat melatonin receptors. We cloned cDNAs including complete ORFs, and $3^{\prime}$ - and $5^{\prime}$-UTRs of rat MT1 and MT2 in a rapid amplification of cDNA end (RACE) method, and identified their gene structures. Furthermore, we confirmed specific melatonin binding to the receptors, and determined the mRNA expression patterns in the central nervous system, several peripheral tissues, and GnRH neurons by RT-PCR.

\section{Materials and methods}

\section{Chemicals}

$2-\left[{ }^{125} \mathrm{I}\right]$-Iodomelatonin $\left({ }^{125} \mathrm{I}-\mathrm{Mel}\right)$ was purchased from GE Healthcare Bio-Sciences (Fairfield, CT). Melatonin, 6-hydroxymelatonin, and $\mathrm{N}$-acetyl-5-hydroxytryptamine (NAS) were obtained from Wako Chemicals (Osaka, Japan), and 2-iodomelatonin (I-Mel) and luzindole from TOCRIS bioscience (Bristol, UK).

Animals

All experiments were performed with the approval of the Nippon Medical School Animal Care Committee. Wistar rats, and transgenic rats that express enhanced green fluorescent protein (EGFP) under control of the GnRH promoter [14] were used in these studies. The rats had free access to water and food, and were kept under a 14-h light, 10-h dark cycle. Rats aged 2-3 months were used.

For total RNA isolation, rats were decapitated under ether anesthesia, and brains and peripheral organs were quickly removed and stored in liquid nitrogen until use.
Cell culture

NIH3T3 (cell number JCRB0615; provided from the Health Science Research Resources Bank, Osaka, Japan), Hela, and HEK293 cells were cultured in high-glucose Dulbecco's modified Eagle's medium (DMEM) (Sigma Chemical, St Louis, MO) supplemented with $1 \mathrm{mM} \mathrm{Na}$ pyruvate, $24 \mathrm{mM} \mathrm{NaHCO}$, $4 \mathrm{mM}$ L-glutamine, $10 \%$ fetal bovine serum (JRH Biosciences, Lenexa, KS), $100 \mathrm{U} / \mathrm{ml}$ penicillin, and $0.1 \mathrm{mg} / \mathrm{ml}$ streptomycin without phenol red. For NIH3T3 cells stably expressing rat MT1 or MT2, $5 \mu \mathrm{g} /$ $\mathrm{ml}$ blasticidin S (Invitrogen, Carlsbad, CA) was added to the culture medium. The cultures were maintained at $37^{\circ} \mathrm{C}$ in a water-saturated atmosphere of $95 \%$ air and $5 \% \mathrm{CO}_{2}$. Cells were routinely passaged every 3-4 days, and used in experiments within 20 passages.

For experiments measuring the I-Mel binding ability and melatonin receptor mRNA expression, cells were cultured in $75-\mathrm{mm}^{2}$ flasks for 3-4 days, then washed three times with phosphate-buffered saline (PBS: $137 \mathrm{mM} \mathrm{NaCl}$, $8.10 \mathrm{mM} \mathrm{Na} \mathrm{HPO}_{4}, 2.68 \mathrm{mM} \mathrm{KCl}, 1.47 \mathrm{mM} \mathrm{KH}_{2} \mathrm{PO}_{4}$, and $0.5 \mathrm{mM}$ EDTA, $\mathrm{pH} 7.4$ ), and pelleted by centrifugation at $300 \times g$ for $5 \mathrm{~min}$. Cell pellets were frozen under liquid nitrogen and stored at $-80^{\circ} \mathrm{C}$ until use.

\section{Total RNA isolation}

Total RNA was extracted using a SV Total RNA Isolation System (Promega, Madison, WI) following the manufacturer's instructions. Total RNA was then treated with Turbo DNase (RNase-free DNase I; Ambion, Austin, TX), and purified. The concentration was quantified by absorption at $260 \mathrm{~nm}$.

\section{$5^{\prime}$ - and $3^{\prime}$ - RACEs of rat melatonin receptors}

The unknown cDNA sequences including $5^{\prime}$ - and $3^{\prime}$-UTRs of rat melatonin receptors were analyzed by $5^{\prime}$ - and $3^{\prime}$ RACEs. 5'-RACE was performed using a concatemer formation method. Total RNA isolated from male rat hypothalamus was reverse-transcribed with $5^{\prime}$-phosphorylated RT primers. Reaction mixtures (final volume $25 \mu \mathrm{l}$ ) contained $10 \mu \mathrm{g}$ of total RNA, $1 \times$ RT buffer, $1 \mathrm{mM}$ dNTP mixture, 5 pmol RT primer, $20 \mathrm{U}$ RNasin Plus (RNase inhibitor; Promega), and $100 \mathrm{U}$ ReverTra Ace (M-MLV reverse transcriptase (RTase), RNase $\mathrm{H}(-)$; TOYOBO, Osaka, Japan). The reaction was carried out at $42^{\circ} \mathrm{C}$ for $60 \mathrm{~min}$, and stopped by heating at $75^{\circ} \mathrm{C}$ for $15 \mathrm{~min}$. Subsequently, single-strand cDNA was obtained using RNase $\mathrm{H}$ (Takara bio, Shiga, Japan). 5'-phosphorylated single-strand cDNA was concatemerized by T4 RNA ligase (Takara bio), and two-round PCR with gene-specific primers was performed to amplify the 5'-RACE products. The first strand 
cDNA for 3'-RACE was synthesized from male rat hypothalamus total RNA with adapter-oligo $(\mathrm{dT})_{18}$ primers. $3^{\prime}$ RACE fragments were amplified using two-round PCR with gene-specific primers and 3 -RACE adapter primers. The conditions for the first- and second-round PCRs consisted of 28 cycles of $94^{\circ} \mathrm{C}$ for $30 \mathrm{~s}, 60^{\circ} \mathrm{C}$ for $20 \mathrm{~s}$ and $72^{\circ} \mathrm{C}$ for $1 \mathrm{~min}$, with an initial denaturing at $94^{\circ} \mathrm{C}$ for $2 \mathrm{~min}$ and a final elongation of $72^{\circ} \mathrm{C}$ for $5 \mathrm{~min}$. The reaction was performed in $50 \mu \mathrm{l}$ of reaction mixture comprising the RACE cDNAs corresponding to $1 \mu \mathrm{g}$ of total RNA, $1 \times$ GC PCR buffer, $0.4 \mathrm{mM}$ dNTP mixture, $0.4 \mu \mathrm{M}$ forward and reverse primers, and 1.2 U LA Taq polymerase (Takara bio). The oligonucleotide primers used in RACEs are listed in Table 1. RACE products were excised, purified, and cloned into pGEM-T-Easy vectors (Promega). The complete ORFs, and $5^{\prime}-$ and $3^{\prime}$-UTRs of rat MT1 and MT2 cDNAs were identified by DNA sequencing.

Construction of NIH3T3 cells that stably express rat MT1 or MT2

Rat MT1 and MT2 cDNAs were first amplified with LA Taq polymerase, cloned into pGEM-T-Easy vectors, and sequenced. The ORFs of the receptors were then amplified from pGEM-T-Easy-rat MT1 or pGEM-T-Easy-rat MT2 vectors using the primers shown in Table 1 , subcloned into pcDNA6.2-Gatway Directional TOPO vectors (Invitrogen), and confirmed by DNA sequencing. Recombinant plasmid
Table 1 Primers used for $3^{\prime}$-, 5 -RACE, ORF cloning, and plasmid construction
To design the primers for cloning of rat MT1 and MT2, we referred to AF130341 for MT1 and AF141863 for MT2

\begin{tabular}{|c|c|c|}
\hline Gene & Direction & Primer sequences \\
\hline \multicolumn{3}{|l|}{$3^{\prime}$-RACE } \\
\hline \multicolumn{3}{|l|}{ Universal } \\
\hline RT primer & Reverse & $5^{\prime}$-GCTGTCAACGATACGCTACGTAACGGCATGACAGTG(T) $18^{-3^{\prime}}$ \\
\hline 1st PCR & Reverse & 5'-GCTGTCAACGATACGCTACGTAACG-3' \\
\hline 2nd PCR & Reverse & $5^{\prime}$-CGCTACGTAACGGCATGACAGTG-3' \\
\hline \multicolumn{3}{|l|}{ MT1 } \\
\hline 1st PCR & Forward & 5'-AAACCGGACAGCAAACCCAAACT-3' \\
\hline 2nd PCR & Forward & 5'-GGGCCCCACTCAACTTCATAGGTC-3' \\
\hline \multicolumn{3}{|l|}{ MT2 } \\
\hline 1st PCR & Forward & 5'-CCGAAGGAAGGCAAAGGCTGAGAG-3' \\
\hline 2nd PCR & Forward & 5'-CCAGAAGGGCTTTTTGTCACCAG-3' \\
\hline \multicolumn{3}{|l|}{$5^{\prime}$-RACE } \\
\hline \multicolumn{3}{|l|}{ MT1 } \\
\hline RT primer & Reverse & $5^{\prime}$-pAGTAACTAGCCACGAAGA-3' \\
\hline \multirow[t]{2}{*}{ 1st PCR } & Forward & 5'-AAACCGGACAGCAAACCCAAACT-3' \\
\hline & Reverse & 5'-GCCCAGGATGTCCACCACGATAGT-3' \\
\hline \multirow[t]{2}{*}{ 2nd PCR } & Forward & 5'-GGGCCCCACTCAACTTCATAGGTC-3' \\
\hline & Reverse & $5^{\prime}$-ACGACGGCCGCGATCTTATTTC-3' \\
\hline \multicolumn{3}{|l|}{ MT2 } \\
\hline RT primer & Reverse & $5^{\prime}$-pATTAAGGCAGCTGTTGAA- $3^{\prime}$ \\
\hline \multirow[t]{2}{*}{ 1st PCR } & Forward & 5'-CCGAAGGAAGGCAAAGGCTGAGAG-3' \\
\hline & Reverse & 5'-GGTGCTGGCTGTCTGGATGAAGGT-3' \\
\hline \multirow[t]{2}{*}{ 2nd PCR } & Forward & 5'-CCAGAAGGGCTTTTTGTCACCAG-3' \\
\hline & Reverse & 5'-TGACTGCAGGCTCGGTGGTAGGT-3' \\
\hline \multicolumn{3}{|l|}{ ORF cloning } \\
\hline \multirow[t]{2}{*}{ MT1 } & Forward & 5'-GCGCGGGGCTACAGGATGATG-3' \\
\hline & Reverse & 5'-CAGGAGGTCCGCTCCAACACTATG-3' \\
\hline \multirow[t]{2}{*}{ MT2 } & Forward & 5'-GGAGCGCCCCCAAGCAGT-3' \\
\hline & Reverse & 5'-AGGTCAAGGTGGCAGGGAAAATG-3' \\
\hline \multicolumn{3}{|c|}{ Plasmid construction } \\
\hline \multirow[t]{2}{*}{ MT1 } & Forward & 5'-CACCATGAAGGGCAATGTCAGC-3' \\
\hline & Reverse & 5'-TTAAACAGAGTCCACCTTTATTAAATT-3' \\
\hline \multirow[t]{2}{*}{ MT2 } & Forward & 5'-CACCATGCCTGACAACAGCTCCAT-3' \\
\hline & Reverse & $5^{\prime}$-CTAGAGAGCACCTTCCTGGACAG-3' \\
\hline
\end{tabular}


vectors (pcDNA6.2-rat MT1 or pcDNA6.2-rat MT2) were introduced into NIH3T3 cells using a GeneJuice Transfection Reagent (Novagen, Darmstadt, Germany), according to the manufacturer's instructions. Cells were cultured in supplemented DMEM containing $5 \mu \mathrm{g} / \mathrm{ml}$ blasticidin $\mathrm{S}$ until the resistant clones were apparent. Each colony was picked up, and the cells were dispersed and plated onto 96-well culture plates at a concentration of 0.1 cells/well. The clones were tested by the I-Mel binding assay and RT-PCR analysis, and positive clones were maintained for subsequent experiments.

\section{I-Mel binding assay}

Cell pellets were homogenized in binding buffer $(50 \mathrm{mM}$ Tris- $\mathrm{HCl}$ and $1 \mathrm{mM} \mathrm{MgCl}_{2}$ ) and briefly sonicated. The protein concentration was measured using a BCA Protein Assay Reagent Kit (Pierce, Rockford, IL). Cell lysates $(1 \mathrm{mg} / \mathrm{ml}$ whole cell protein) were incubated in $200 \mu \mathrm{l}$ binding buffer with $0.1 \mathrm{mg} / \mathrm{ml}$ bovine serum albumin and ${ }^{125} \mathrm{I}$-Mel for $12 \mathrm{~h}$ at room temperature $\left(25^{\circ} \mathrm{C}\right)$. In saturation studies, ${ }^{125} \mathrm{I}-\mathrm{Mel}$ was added at concentrations ranging from 1 to $200 \mathrm{pM}$. In competition curves with melatonin and its analogues, the radioligand concentration was $100 \mathrm{pM}$. Incubation was terminated by dilution with $5 \mathrm{ml}$ of ice-cold binding buffer, followed by filtration through glass-fiber filters (Whatman, Wheeling, IL). The filters were washed four times with $5 \mathrm{ml}$ binding buffer. Non-specific binding was assessed in the presence of $20 \mu \mathrm{M}$ cold melatonin.

\section{RT-PCR}

Total RNA was reverse-transcribed into first-strand cDNA using oligo(dT) primer. Reaction mixtures (final volume $25 \mu \mathrm{l}$ ) contained $10 \mu \mathrm{g}$ of total RNA, $1 \times$ RT buffer, $1 \mathrm{mM}$ dNTP mixture, $1 \mu \mathrm{g}$ oligo(dT) 15 (Promega), $20 \mathrm{U}$ RNasin Plus (Promega), and $100 \mathrm{U}$ ReverTra Ace (TOYOBO). The reaction was carried out at $42^{\circ} \mathrm{C}$ for $60 \mathrm{~min}$, and stopped by heating at $75^{\circ} \mathrm{C}$ for $15 \mathrm{~min}$. cDNA was treated with $4 \mathrm{U}$ of RNase $\mathrm{H}$ at $37^{\circ} \mathrm{C}$ for $30 \mathrm{~min}$, and stored at $-20^{\circ} \mathrm{C}$ until use.

PCR was performed in $25 \mu \mathrm{l}$ of reaction mixture comprising cDNA corresponding to $200 \mathrm{ng}$ of total RNA, $1 \times$ PCR buffer, $0.2 \mathrm{mM}$ dNTP mixture, $0.2 \mu \mathrm{M}$ forward and reverse primers, and $0.63 \mathrm{U}$ Blend Taq polymerase (TOYOBO). PCR was performed in three steps, with a PCR cycle reaction of $95^{\circ} \mathrm{C}$ for $30 \mathrm{~s}, 60^{\circ} \mathrm{C}$ for $20 \mathrm{~s}$, and $72^{\circ} \mathrm{C}$ for $30 \mathrm{~s}$, with an initial denaturing at $95^{\circ} \mathrm{C}$ for $2 \mathrm{~min}$ and a final elongation at $72^{\circ} \mathrm{C}$ for $5 \mathrm{~min}$. The sequences of oligonucleotide primers used in RT-PCR are shown in Table 2. To avoid amplifying any contaminating genomic DNA, the primer pairs were designed from different exons.
Table 2 Primers used for RTPCR and multi-cell RT-PCR

Forward and reverse primers were designed on different exons to distinguish the amplification of cDNA templates from that of contaminating genomic DNA.

To design the PCR primers, we referred to the following nucleotide sequences: AB377274 for MT1, AB377275 for MT2, NM_031144 for $\beta$ actin, NM_008084 for mGAPDH, and M12579 for GnRH

\begin{tabular}{|c|c|c|c|}
\hline Gene & Direction & Primer sequences & Product size (bp) \\
\hline \multicolumn{4}{|l|}{ RT-PCR } \\
\hline \multirow[t]{2}{*}{ MT1 } & Forward & 5'-ATGGCCCTGGCTGTGCTGCGGTAAG-3' & 316 \\
\hline & Reverse & 5'-TAAGTATAGACGTCAGCGCCAAGGGAAATG-3' & \\
\hline \multirow{2}{*}{ MT2 } & Forward & 5'-GGAGCGCCCCCAAGCAGTG-3' & 390 \\
\hline & Reverse & 5'-GGATCTCCCCAAGTACCCAACCGTCAT-3' & \\
\hline \multirow[t]{2}{*}{$\beta$-Actin } & Forward & 5'-GTCCACACCCGCCACCAGT-3' & 496 \\
\hline & Reverse & 5'-CGTCTCCGGAGTCCATCACAAT-3' & \\
\hline \multirow[t]{2}{*}{ mGAPDH } & Forward & 5'-TGAAGGTCGGTGTGAACGGATTTG-3' & 359 \\
\hline & Reverse & 5'-GGCGGAGATGATGACCCTTTTG-3' & \\
\hline \multicolumn{4}{|c|}{ Multi-cell RT-PCR } \\
\hline \multicolumn{4}{|l|}{ MT1 } \\
\hline \multirow[t]{2}{*}{ 1st PCR } & Forward & 5'-ATGGCCCTGGCTGTGCTGCGGTAAG-3' & 442 \\
\hline & Reverse & 5'-TGTGGCAAATGTAGCAGTAGCGGTTCA-3' & \\
\hline \multirow[t]{2}{*}{ 2nd PCR } & Forward & $5^{\prime}$-CAGGCGGCGGGGAGGAAATAAG- $3^{\prime}$ & 231 \\
\hline & Reverse & $5^{\prime}$-TAAGTATAGACGTCAGCGCCAAGGGAAATG-3' & \\
\hline \multicolumn{4}{|l|}{ MT2 } \\
\hline \multirow[t]{2}{*}{ 1st PCR } & Forward & $5^{\prime}$-GGAGCGCCCCCAAGCAGTG-3' & 390 \\
\hline & Reverse & 5'-GGATCTCCCCAAGTACCCAACCGTCAT-3' & \\
\hline \multirow[t]{2}{*}{ 2nd PCR } & Forward & $5^{\prime}$-CGGGCTGCAGCGTCACCAT-3' & 275 \\
\hline & Reverse & 5'-GTCAGCCAAGGCCAGATTCACC-3' & \\
\hline \multirow[t]{2}{*}{ GnRH } & Forward & 5'-ACTGATGGCCGCTGTTGTTCT-3' & 256 \\
\hline & Reverse & 5'-СТTСТTCTGCССАGCTTCСТСТTCA-3' & \\
\hline
\end{tabular}




\section{Multi-cell RT-PCR}

Slice preparation and cell harvest are described in detail elsewhere $[15,16]$. In brief, coronal slices $(200 \mu \mathrm{m}$ thick) containing medial septum, diagonal band of Broca, organum vasculosum of the lamina terminalis and medial preoptic area were prepared from adult male and female transgenic rats. The slice was viewed under an uplight fluorescence microscope (BX50; Olympus, Tokyo, Japan). The cytoplasmic contents were harvested from five GnRH neurons under visual control, and pooled in a thin-wall PCR tube containing RNasin Plus.

The harvested contents were heated with random hexamer primers (Promega), at $95^{\circ} \mathrm{C}$ for $5 \mathrm{~min}$ and then cooled on ice for $1 \mathrm{~min}$. The reverse transcription mixture $(50 \mu \mathrm{l})$ contained cytoplasmic contents from five cells, $1 \times \mathrm{RT}$ buffer, $1 \mathrm{mM}$ dNTP mixture, $500 \mathrm{ng}$ random hexamer primers, fresh $40 \mathrm{U}$ RNasin Plus, and $200 \mathrm{U}$ ReverTra Ace. Reverse transcription was carried out at $30^{\circ} \mathrm{C}$ for $10 \mathrm{~min}$ and then $42^{\circ} \mathrm{C}$ for $45 \mathrm{~min}$. After stopping the reaction by heating at $75^{\circ} \mathrm{C}$ for $15 \mathrm{~min}$, the reaction mixture was treated with $\mathrm{RNase} \mathrm{H}$ at $37^{\circ} \mathrm{C}$ for $30 \mathrm{~min}$ and stored at $-80^{\circ} \mathrm{C}$ until use.

To confirm successful cDNA synthesis from the cytoplasmic contents of GnRH neurons, one-round PCR amplification was performed using $10 \mu \mathrm{l}$ aliquots of the reverse transcription mixture as a template. For melatonin receptors, two-round PCR amplification was performed using $20 \mu \mathrm{l}$ aliquots of the reverse transcription mixture as a template for the first PCR and $0.5 \mu l$ aliquots of the first PCR solution as a template for the nested PCR. The PCR conditions were $94^{\circ} \mathrm{C}$ for $2 \mathrm{~min}, 26$ cycles for MT1 and 28 cycles for MT2 of $94^{\circ} \mathrm{C}$ for $30 \mathrm{~s}, 60^{\circ} \mathrm{C}$ for $20 \mathrm{~s}$, and $72^{\circ} \mathrm{C}$ for $30 \mathrm{~s}$, and finally $72^{\circ} \mathrm{C}$ for $5 \mathrm{~min}$. The PCR mixture $(50 \mu \mathrm{l})$ contained template DNA, $1 \times$ PCR buffer, $0.2 \mathrm{mM}$ dNTP mixture, $0.2 \mu \mathrm{M}$ forward and reverse primers, and 1.2 U Blend Taq polymerase. Primer sequences are shown in Table 2.

\section{Electrophoresis}

PCR products $(5 \mu \mathrm{l})$ were separated by electrophoresis on $2 \%$ agarose gels, and visualized by ethidium bromide staining under UV irradiation. Gel images were captured using a FAS-III system (TOYOBO).

\section{DNA sequencing}

PCR products were extracted from agarose gels using a Wizard SV Gel and PCR Clean-up System (Promega), and cloned into pGEM-T-Easy vectors (Promega). Sequencing reactions were performed using a BigDye Terminator v3.1 Cycle Sequencing Kit (Applied Biosystems, Foster City,
CA). Fluorescent signals were detected using an ABI PRISM 310 Genetic Analyzer (Applied Biosystems).

\section{Results}

Cloning and sequencing of rat MT1 and MT2 cDNAs

According to the partial cDNA sequences (accession number AF130341 for MT1 and accession number AF141863 for MT2 [9]), primers were synthesized for $3^{\prime}$ - and $5^{\prime}$-RACEs to obtain the remaining sequences of rat MT1 and MT2 cDNAs. The cloned cDNA sequences of rat MT1 (accession number AB377274) and MT2 (accession number AB377275) contained 1,775 and 1,858 bp nucleotides, consisting of 206 and 115 bp of $5^{\prime}$-UTR, 1,062 and 1,095 bp ORF, and 507 and 648 bp 3'-UTR, respectively (Fig. 1). We identified two other forms of rat MT1 transcripts resulting from multiple polyadenylation signals (underlined in Fig. 1a).

These sequences exhibited the typical structures of the G-protein coupled receptor family. Two subtypes of rat receptors share $54.7 \%$ identity with each other at the amino acid level. When compared with other mammalian melatonin receptors, rat MT1 shows 84.1 and $92.6 \%$ identity (Fig. 1c), and rat MT2 exhibits $78.3 \%$ and $88.7 \%$ identity with the respective human and mouse receptors (Fig. 1d).

\section{Genomic organization of rat MT1 and MT2}

Using a BLAT alignment program [17], we mapped the rat MT1 and MT2 cDNA sequences on the rat genome version 3.4 (Fig. 2). Rat MT1 gene is located at 16q11 on rat chromosome 16 and consists of two exons (Fig. 2a). This structure is homologous to that of the human and mouse MT1 genes. Rat MT2 gene lies at 8q12 on rat chromosome 8 , and consists of three exons (Fig. 2b). The $5^{\prime}$ - and $3^{\prime}$-ends of the introns of both genes conform to the GT-AG rule for splicing. We newly identified mouse MT2 cDNA containing $5^{\prime}$ - and $3^{\prime}$-UTRs (accession number AB377276), and mapped it on the Build 37 mouse genome assembly (Suppl. Fig. 1A). The rat MT2 gene has a homologous structure with the mouse gene. Using RT-PCR with specific primers designed on exon 2 and 3, we further confirmed that these MT2 genes were properly transcribed (Suppl. Fig. 1B). In contrast, the human MT2 gene consists of two exons (accession number BC069163, data not shown).

Biochemical properties of rat MT1 and MT2

To characterize the biochemical properties of rat MT1 and MT2 using homogeneous biological materials, we 
(a)

rat melatonin receptor la (MT1)

1

27 ggctggagceggetaeggggcaggaccgcgar

87 ggagggctctccccagccataaaaagtggcggagagggcgcaagcagagctgggcacttg

147 agggcgcggggctacaggatgatggccctggctgtgctgcggtaagtcacccaggggacc

207 atgaagggcaatgtcagcgagcttctcaacgcctctcagcaggctccaggcggcggggag

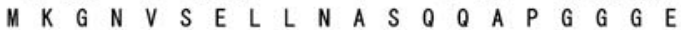

267 gaaataagatcgcggccgtcgtggctggcctctacactggccttcatcctcatctttact $E$ I $R$ S R P S W L A S T L A F I L I F

327 atcgtggtggacatcctgggcaacctgctggtcatcctgtctgtgtatcgcaacaagaag $\begin{array}{llllllllllllllllllll}\text { I } & V & V & D & \text { I } & \text { L } & G & N & \text { L } & \text { L } & \text { V } & \text { I } & \text { L } & S & V & \text { Y } & R & N & K & K\end{array}$

387 ctcaggaacgcagggaatatatttgtggtgagtttagctgtggcagacctcgtggtggct $\begin{array}{llllllllllllllllllll} & R & N & A & G & N & \text { I } & F & V & V & S & L & A & V & A & D & L & V & V & A\end{array}$

447 atttacccatttccettggcgctgacgtctatacttaacaatggatggaacctgggatat $\begin{array}{llllllllllllllllllll}I & Y & P & F & P & L & A & L & T & S & \text { I } & L & N & N & G & W & N & L & G & Y\end{array}$

507 ctgcattgtcaagttagtgccttcctaatgggcctgagtgtcattggctcggtattcaac L H C 0 V S A F L M G L S V I G S V F N

567 atcaccgggatcgctatgaaccgctactgctacatttgccacagtctcaagtatgatagg

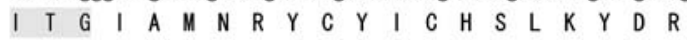

627 atatacagtaacaagaattccctgtgctacgtgttcctgatatggacactgacactcata

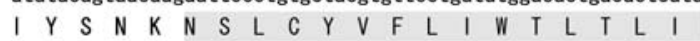

687 gccatcatgcccaacctgcaaaccggaactctccagtacgacccccggatctactcctgt

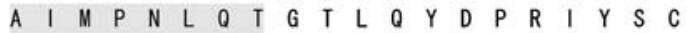

747 accttcacccagtccgtcagctcggcgtacacgattgccctggtggttttccatttcgta $\begin{array}{llllllllllllllllllll}T & F & T & Q & S & V & S & S & A & Y & T & \text { I } & A & L & V & V & F & H & F & V\end{array}$

807 gttccaatgattattgtcactttctgctacttaaggatatggatcctggttcttcaggtc $\begin{array}{lllllllllllllllllllll}V & P & M & \text { I } & \text { I } & V & T & F & C & Y & L & R & \text { I } & \text { W } & \text { I } & \text { L } & V & L & 0 & \text { V }\end{array}$

867 agacggagggtgaaaccggacagcaaacccaaactgaagccgcaggacttcaggaacttt

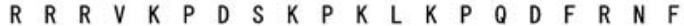

927 gtcaccatgtttgtagttttgtactttttgccetgtgctgggccccactcaacttcata V T M F V V F V L F A L C W A P L

987 ggtcttattgtggcctcagatccggccgccatggcccccaggatcccggagtggctcttc G L I V A S D P A A M A P R I P E W L F

1047 gtggctagttactacctggcgtatttcaacagctgcctcaacgcaatcatatacggacta

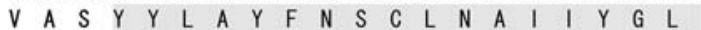

1107 ctgaaccaaaatttcagaaaggagtacaagaggattatcatctcactgtgcacagctaag

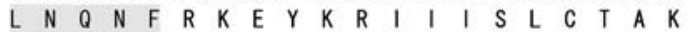

1167 atgttctttgtggacagttcaaatgatgcagcagataagattaaatgtaagccctctcca

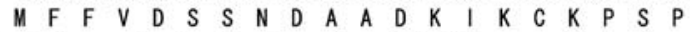

1227 ctaataaccaataataatttaataaaggtggactctgtttaaaaagc clagtggtgccag

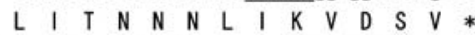

1287 caggttacgctcgctggttggggtcttactgctttctcttgtctagaaatcaatctatcc

1347 atcttgaagctctcaagagttgccagcatagtgttggagcggacctcctgtctgcccttt

1407 aatcagatcttcagtatcaaggggaatactgaacacgcacaaaggtatatgtgcagactc

1467 tcatctctgggtgaccaggtcttaggggcccacacttagcattacaataacatagcaaca

1527 caccaaagctgaacaaaatgtgagatgaattcaagagaggccgtgggcacctttcttttg

1587 ttgcaaacaagtgatacagggtgtttattcttacctgtggctgaattaaaatagtcagaa

1647 aaactcacatggacatatatttctttttattggccccttaacaatgcagtgtaatgtac

1707 tagacattatatgtaacccagcaatggtttaaagaactgtattgtgaagttatatgtttg

1767 ttatatacg(poly adenylation)

Fig. 1 Structural analysis of rat melatonin receptor nucleotide and deduced amino acid sequences. cDNA sequences and deduced amino acid sequences of rat MT1 (a) and MT2 (b). The polyadenylation signals are underlined, and the polyadenylation sites are boxed. Shaded regions are transmembrane domains. We registered these two sequences as accession numbers AB377274 for rat MT1 and AB377275 for rat MT2. Alignments of the deduced rat MT1 (c) and MT2 (d) protein amino acid sequences with mouse and human

constructed cell lines that stably express rat MT1 or MT2. We selected NIH3T3 cells as host cells because I-Mel binding assay and RT-PCR analysis revealed that the cells did not express mouse melatonin receptors (Suppl. Fig. 2). (b)

rat melatonin receptor $1 \mathrm{~b}$ (MT2)

1 cctcttggtccctccccacagcctcttcttagcacttgctgggcggggaggggac

56 agcgggagcgccccaagcagtgcacaccttgcgcatctatccegggctgcagcgtcacc

116 atgcctgacaacagctccatcgccaactgctgtgcggccagcgggctggcagcgcgccct

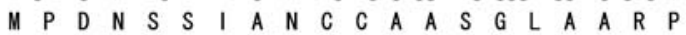

176 agttggcccgggtcagcggaggcggagccccctgagactccccgggcaccctgggtggct

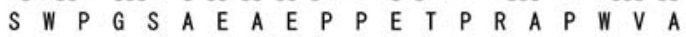

236 cccatgctatctacagtagtcattgtcaccacagctgtggacttcgtggggaacctgctt P M L S T V V I V T T T A V V D F V

296 gtgatcctctcggtgctcaggaaccgcaagctgcggaacgcaggtaatttatttgtggtg $\begin{array}{lllllllllllllllllllll}V & \text { I } & L & S & V & L & R & N & R & K & L & R & N & A & G & N & L & F & V & V\end{array}$

356 aatctggccttggctgacctggtggtagccctgtacccttacccactcatccttgtggcc

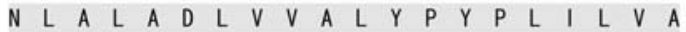

416 attctccatgacggttgggtacttggggagatccactgtaaggccagtgcctttgtgatg I L H D G W V L G E I

476 ggcctgagtgtcattggctctgtcttcaacatcacagccattgccatcaaccgctactgg G L S S V I G $S$ S V F

536 tgcatctgtcacagtgcgacctaccaccgagcctgcagtcagtggcatgctcccctctac C I C

596 atcagcctcatctggcttctcactctggtggccttggtgcccaatttctttgtggggtct I S L I W L L T L V A L V P N F F V G S

656 ctagaatatgaccegcgaatctattcctgcaccttcatccagacagccagcacccaatac

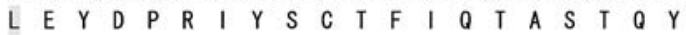

716 actatggctgtggtggccatccacttcctccttccaattgctgtggtgtccttttgctac T M A V V A I H F L L P I A V V S F C Y

776 ctgcgaatatggatactggtgctccaggcccgaaggaaggcaaaggctgagagaaagcta

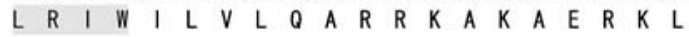

836 cgcctgagacccagtgacctgcgcagtttcctaaccatgttcgcagtgtttgtggttttc $R \quad R \quad P \quad S \quad D L R$ S F L T M F A V F V V F

896 gccatatgctgggccccctcaactgtattggccttgcagtggccatcaatccagaggca A I C W

956 atggctcttcagatcccagaagggctttttgtcaccagttacttcctagcttacttcaac M A L Q I P E G L F V T S Y F L A Y F N

1016 agctgccttaatgctattgtttatgggcttctgaaccagaacttccgcagggagtacaag $S \quad C \quad L \quad N \quad A \quad I \quad V \quad Y \quad G \quad L \quad L \quad N \quad O \quad N \quad F \quad R \quad R \quad E \quad Y \quad K$

1076 aggatcctctcggccctctggagcactgggcgctgcttccatgatgcttccaaatgccac $\begin{array}{llllllllllllllllllll}R & \text { I } & L & S & A & L & W & S & T & G & R & C & F & H & D & A & S & K & C & H\end{array}$

1136 ctgactgaggatttgcagggcccagtgccacctgctgccatggccaccatacctgtccag

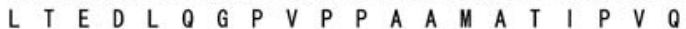

1196 gaaggtgctctctagcctgcatcagctcgtggacctagcagcaaacctgtgaaatgagca E G A L *

1256 gaacggaattgctgtcagtgctgttcaattacttgctcacactgcagcccacaactggtg 1316 aactcaagtgaccacagggacaaacctgcagacactcctaatggcaaactgggcactgga 1376 ttccaattggctgggacagaagtcaagctgtactcataagatgtcattttccctgccacc 1436 ttgacctgttactgaatgttgcctcttccttgaagggccaggggaaaagatctcttgat 1496 tacctgagccgaaagatcaaaatctgcagtgttgaagtgagacttcgttcctatggaagg 1556 agaagtaacctacatctacactcatcgaacagccactgtaacccagaaatcgcagttctg 1616 agagttcagcaataagatcgaagtcaagatctcactgacttacgtgcactcccatgtctg 1676 tgatgatactgctcaaaatggcccagatgtgaaaacatctgttgtattcaaatgttctga 1736 taccccttggcacttagatgaatttcaagtgctggttccattcttagcattttgggtaaa 1796 atgctgtgggtcaaagtggctgcttgatttcagtccaacaaagtgttgatactccaacc 1856 ccc(poly adenylation)

counterparts. Identical amino acids are outlined. Solid lines and arrows indicate transmembrane domains and potential $\mathrm{N}$-glycosylation sites, respectively. Genbank accession numbers referred are as follows: rat MT1 (rMT1), AB377274; mouse MT1 (mMT1), NM_008639; human MT1 (hMT1), NM_005958; rat MT2 (rMT2), AB377275; mouse MT2 (mMT2), AB377276; human MT1 (hMT2), NM_005959

We constructed expression vectors of rat MT1 and MT2 from the identified sequences, and developed NIH3T3 cell lines stably transfected with either rat MT1 or MT2 (Fig. 3). 


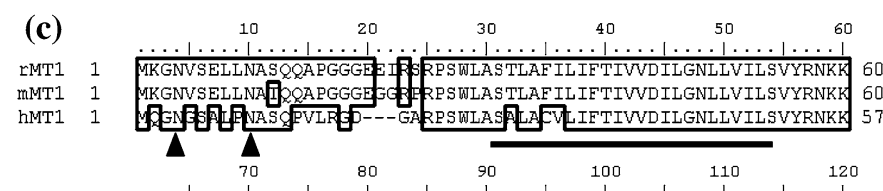

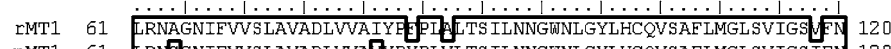
MMT1 61 LRN ONIFWV LAVADLWA GYPYPLVLTS ILNNGWNLGYLHCQVSAFLMGLSVIGS IFN 120 hMT1 58 LRNAGNIFWVSLAVADLWA IYPYPLVI S INNGWNLGYLHCQVSFELMGLSVIGS IFN 117

\begin{tabular}{lllllll}
\hline 130 & 140 & 150 & 160 & 170 & 180
\end{tabular}

rMT1 121 FTGIAMNRYCYICHSLKYD

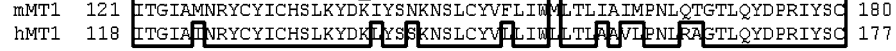

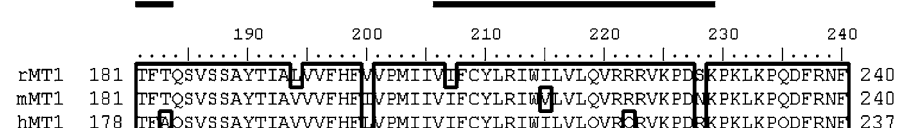

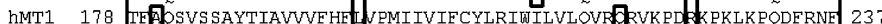

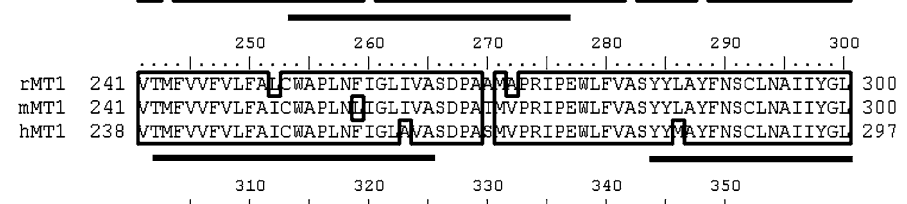

rMT1 301 ENQNERKEYKRII]

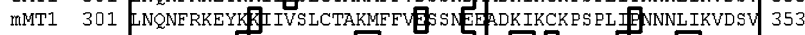

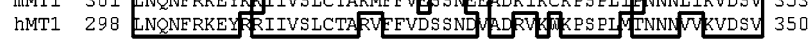

Fig. 1 continued

(a) rat melatonin receptor 1a (MT1)

rat chromosome $16,16 \mathrm{q} 11$

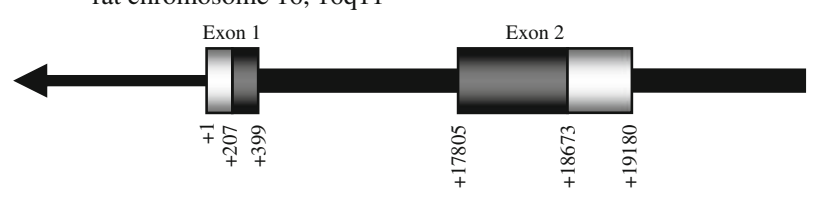

(b) rat melatonin receptor $1 \mathrm{~b}(\mathrm{MT} 2)$ rat chromosome $8,8 \mathrm{q} 12$

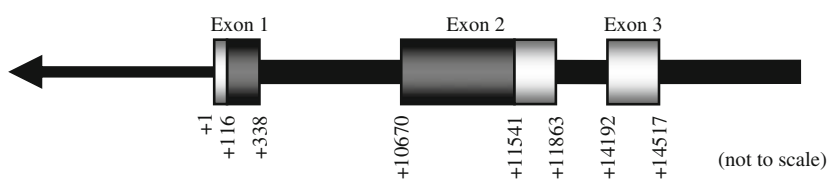

Fig. 2 Genomic organization of rat MT1 and MT2. Schematic representation of rat MT1 (a) and MT2 (b) gene structures. cDNA sequences are mapped on rat genome version 3.4. The rat MT1 gene is located at $16 \mathrm{q} 11$ on rat chromosome 16 , and consists of two exons. On the other hand, rat MT2 gene lies at 8q12 on rat chromosome 8, and consists of three exons. The white and gray boxes indicate the UTRs and ORFs, respectively. The arrows indicate the orientation of the chromosomes. The images are not to scale

Binding and biochemical properties were examined by stable expression of either rat MT1 or MT2 in NIH3T3 cells. Scatchard analysis of the saturation data showed that NIH3T3 cells transfected with either receptor cDNA bound ${ }^{125}$ I-Mel with high affinity (Fig. 4). The $K_{\mathrm{d}}$ values of the cells expressing rat MT1 or MT2 were $73.2 \pm 9.0 \mathrm{pM}$ (mean $\pm \mathrm{SEM} ; n=4$ experiments) and $73.7 \pm 2.9 \mathrm{pM}$ $(n=4)$, respectively. The $B_{\max }$ values were $27.1 \pm 2.7$

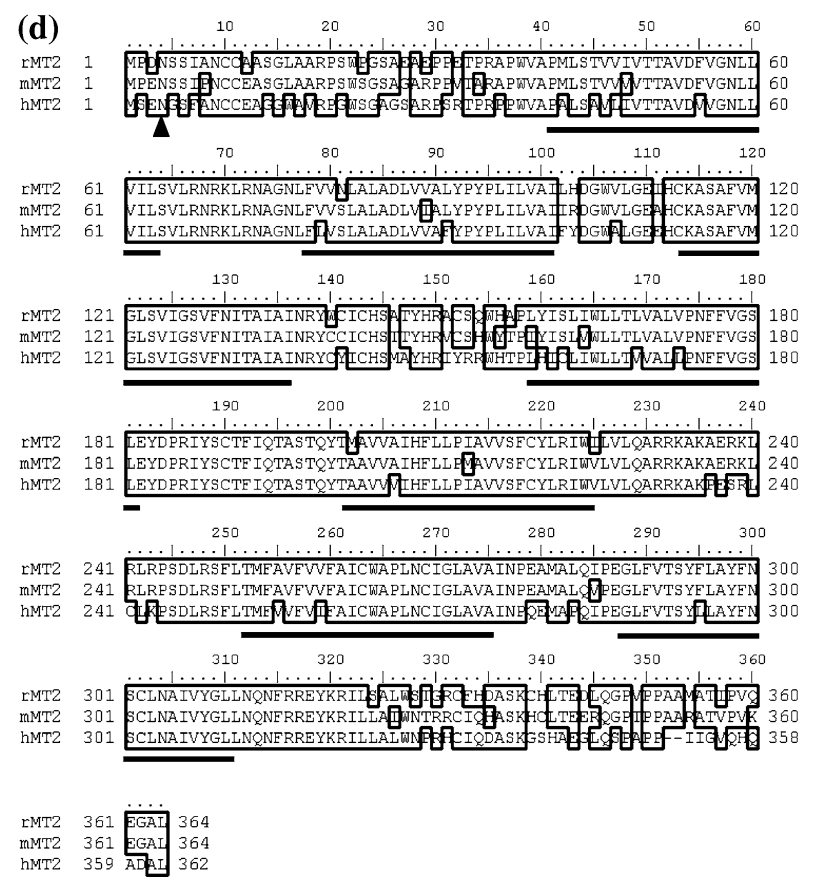



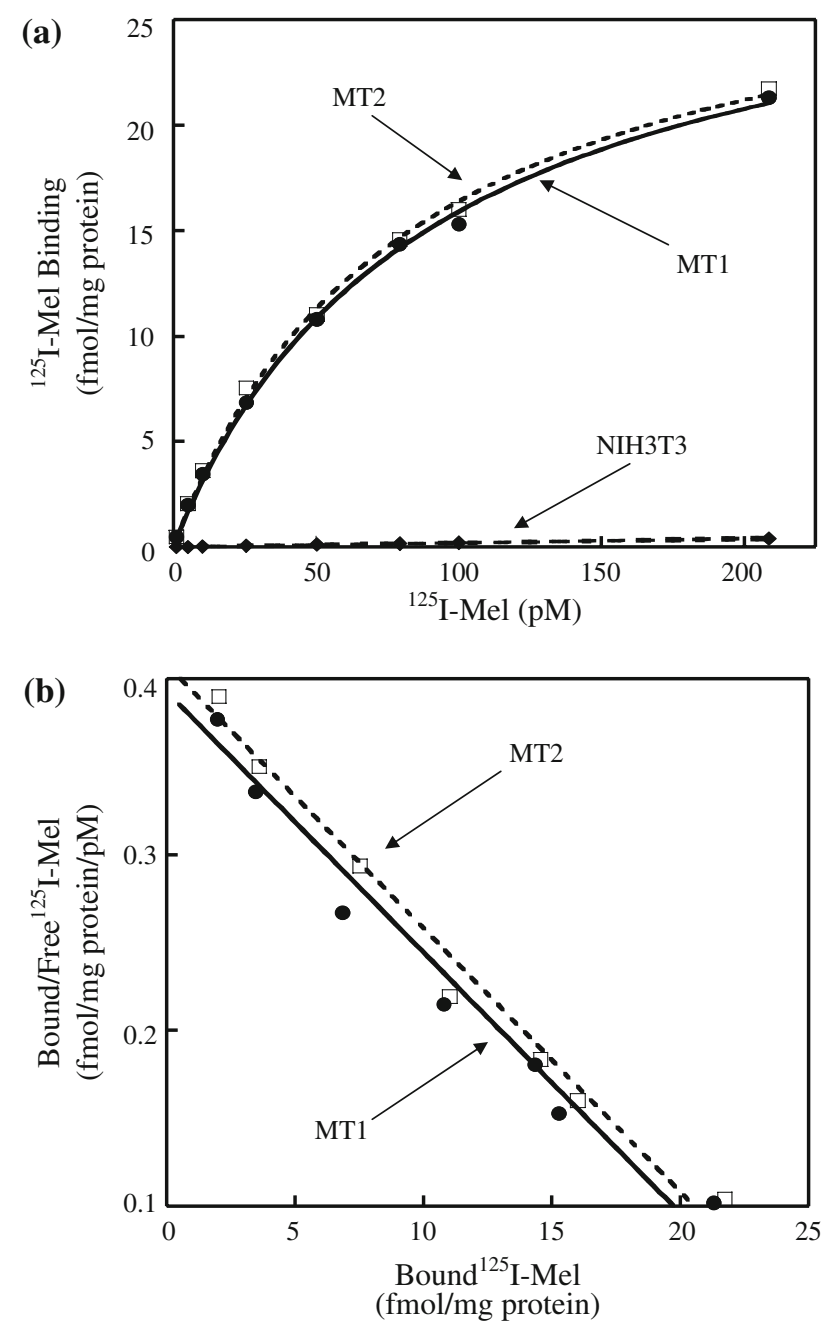

Fig. 4 Scatchard analysis of specific ${ }^{125}$ I-Mel binding to cell lysates prepared from NIH3T3 cells stably expressing either rat MT1 or MT2. a ${ }^{125} \mathrm{I}-\mathrm{Mel}$ saturation binding to rat MT1 or MT2 in NIH3T3 cells. Cell lysates were incubated with various concentrations of ${ }^{125} \mathrm{I}$ Mel (1-200 pM). Non-specific binding was measured in the presence of $20 \mu \mathrm{M}$ melatonin. Specific ${ }^{125} \mathrm{I}-\mathrm{Mel}$ binding is defined as total binding minus non-specific binding. b Scatchard plots of saturation binding to rat MT1 and MT2. The $K_{\mathrm{d}}, B_{\max }$, and Hill's values depicted are $67.6 \mathrm{pM}, 26.5 \mathrm{fmol} / \mathrm{mg}$ of whole cell protein, and 1.01 for rat MT1, and $66.7 \mathrm{pM}, 27.2 \mathrm{fmol} / \mathrm{mg}$, and 1.01 for rat MT2, respectively. Data shown are representative of four experiments. The $K_{\mathrm{d}}, B_{\max }$, and Hill's values of four experiments are $73.2 \pm 9.0 \mathrm{pM}$ $($ mean $\pm \mathrm{SEM}), 27.1 \pm 2.7 \mathrm{fmol} / \mathrm{mg}$, and $1.01 \pm 0.02$ for rat MT1, and $73.7 \pm 2.9 \mathrm{pM}, 30.0 \pm 2.4 \mathrm{fmol} / \mathrm{mg}$, and $1.00 \pm 0.01$ for rat MT2, respectively

Distribution of rat MT1 and MT2 mRNAs in rat brain subregions and peripheral organs

We determined the distribution of MT1 and MT2 mRNAs in rat brain subregions, and peripheral organs by RT-PCR (Fig. 6). MT1 mRNA was widely expressed and was strongly expressed in the hypothalamus, lung, kidney,
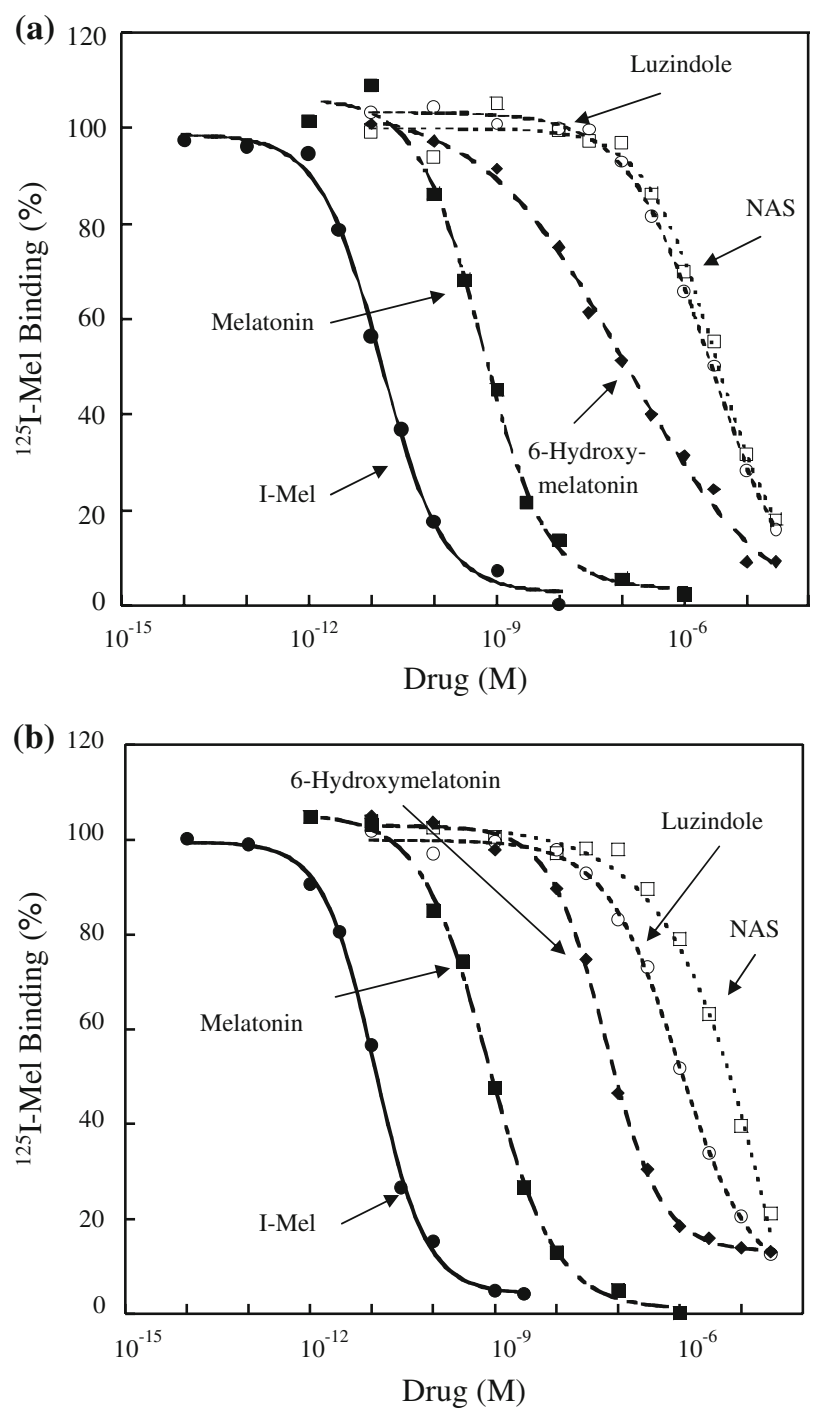

Fig. 5 Competition curves for inhibition of specific ${ }^{125} \mathrm{I}-\mathrm{Mel}$ binding by melatonin and its analogues in NIH3T3 cells stably expressing either rat MT1 or MT2. Cell lysates were incubated with $100 \mathrm{pM}^{125} \mathrm{I}$ $\mathrm{Mel}$ and various concentrations of 2-iodomelatonin (I-Mel), melatonin, 6-hydroxymelatonin, luzindole, or $\mathrm{N}$-acetyl-5-hydroxytryptamine (NAS). Non-specific binding was determined in the presence of $20 \mu \mathrm{M}$ melatonin. Competition binding with various ligands in NIH3T3 cells transfected with either rat MT1 (a) or MT2 (b). The data shown are mean values of four experiments for each drug. The $K_{\mathrm{i}}$ values are listed in Table 3

adrenal gland, stomach, and ovary. The intensity of MT1 signals was faint in the cerebral cortex, hippocampus, and cerebellum but, using 36 cycles of PCR amplification, dense bands were observed (data not shown). We could also observe the wide distribution of MT2 mRNA, although a relatively large number of PCR cycles (37 or 38 cycles) were required to detect the expression. High expression of MT2 was observed in the hippocampus, kidney, and ovary. 
Table 3 Competition of various ligands for specific ${ }^{125} \mathrm{I}-\mathrm{Mel}$ binding in NIH3T3 cells transfected with either rat MT1 or MT2 cDNA

\begin{tabular}{|c|c|c|c|}
\hline \multirow[t]{2}{*}{ Compound } & \multicolumn{2}{|l|}{$K_{\mathrm{i}}$} & \multirow{2}{*}{$\begin{array}{l}\text { Ratio } \\
\text { (MT2/ } \\
\text { MT1) }\end{array}$} \\
\hline & MT1 & MT2 & \\
\hline I-Mel & $6.22 \pm 0.57 \mathrm{pM}$ & $4.81 \pm 0.42 \mathrm{pM}$ & 0.77 \\
\hline Melatonin & $290 \pm 31 \mathrm{pM}$ & $378 \pm 23 \mathrm{pM}$ & 1.31 \\
\hline 6-Hydroxymelatonin & $118 \pm 68 \mathrm{nM}$ & $31.7 \pm 4.9 \mathrm{nM}$ & 0.27 \\
\hline Luzindole & $1.15 \pm 0.19 \mu \mathrm{M}$ & $433 \pm 138 \mathrm{nM}$ & 0.38 \\
\hline NAS & $1.65 \pm 0.42 \mu \mathrm{M}$ & $4.98 \pm 2.84 \mu \mathrm{M}$ & 3.00 \\
\hline
\end{tabular}

The $K_{\mathrm{i}}$ values are mean $\pm \mathrm{SEM}$ of four experiments for each compound

I-Mel 2-iodomelatonin, $N A S N$-acetyl-5-hydroxytryptamine

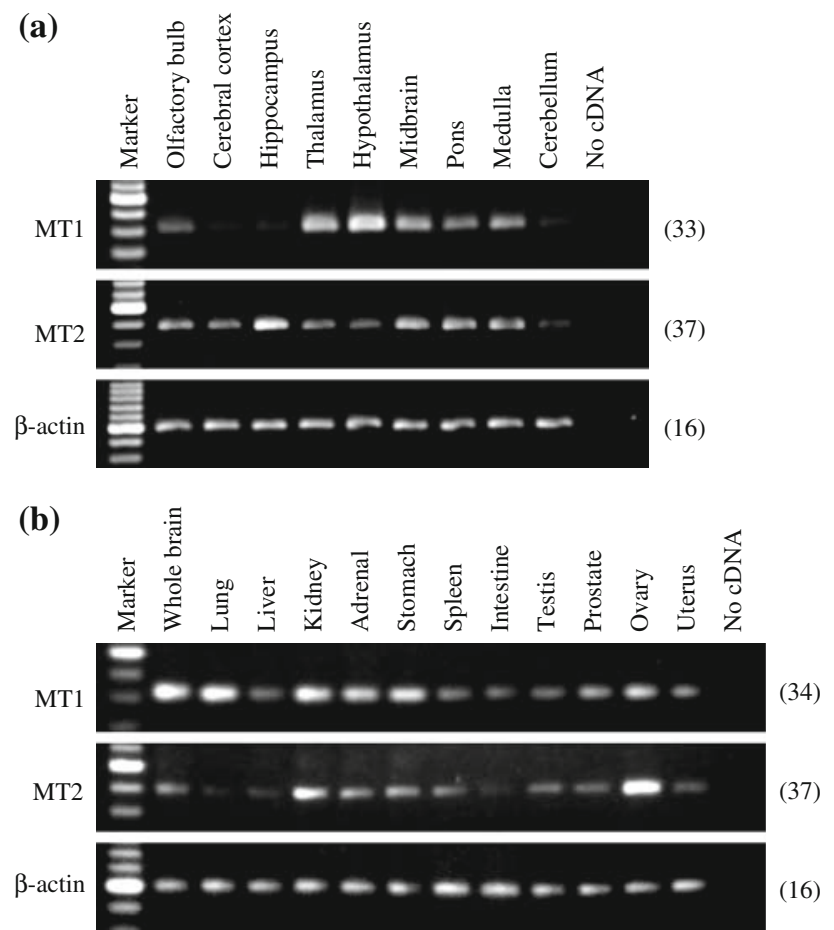

Fig. 6 RT-PCR analysis of MT1 and MT2 mRNA expression in various brain subregions and peripheral organs. Total RNA isolated from various brain subregions and peripheral organs was subjected to RT-PCR using specific primers for MT1, MT2 and $\beta$-actin cDNAs. a Expression of MT1 (upper panel), MT2 (middle panel), and $\beta$-actin (lower panel) in rat brain subregions. b Expression of MT1 (upper panel), MT2 (middle panel) and $\beta$-actin (lower panel) in rat whole brain and peripheral organs. The number on the right of each panel indicates the number of PCR cycles performed. Similar patterns of expression were observed in three different samples

Expression of rat MT1 and MT2 mRNAs in adult rat GnRH neurons

Multi-cell RT-PCR was performed to examine the expression of mRNAs encoding MT1 and MT2 in adult
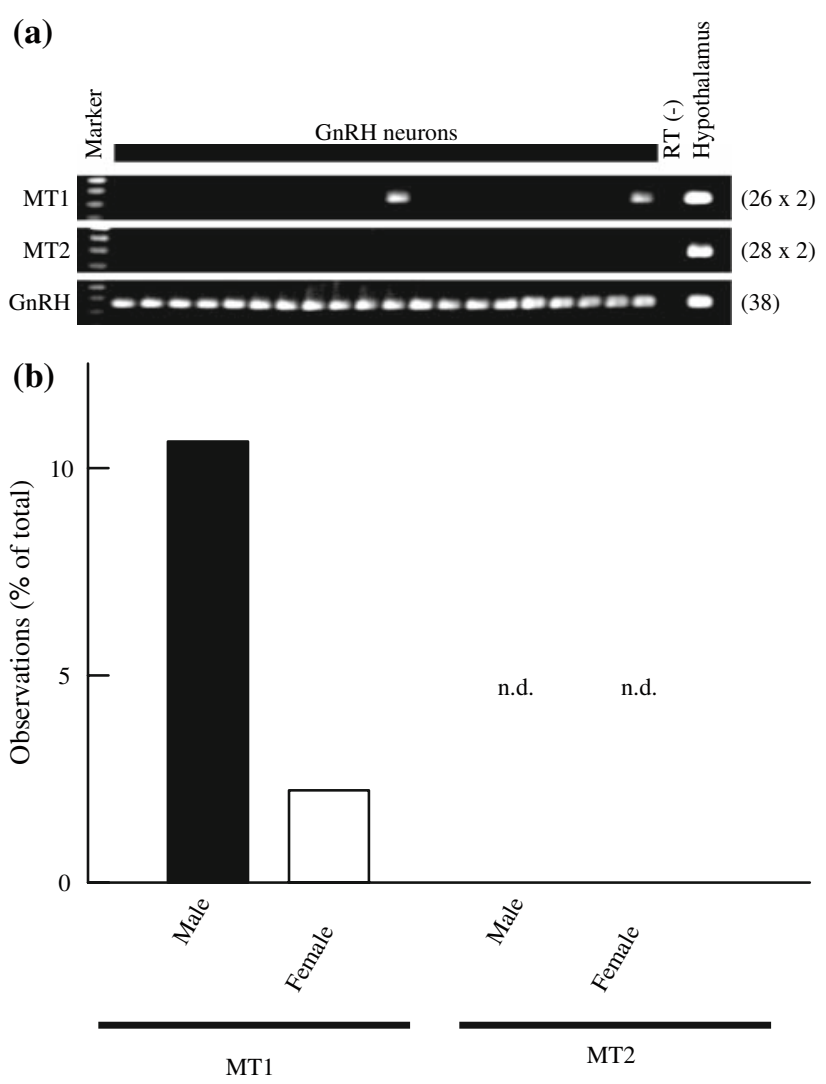

Fig. 7 Multi-cell RT-PCR analysis of mRNAs encoding rat MT1 and MT2 in adult male and female rat GnRH neurons. Cytoplasmic contents harvested from five GnRH neurons were pooled and reversetranscribed to generate cDNA. The amount of cDNA corresponding to two GnRH neurons was examined with each of the primer pairs for rat MT1 and MT2. For GnRH transcripts, the amount of cDNA corresponding to one GnRH neuron was used. a Representative gel images of MT1 (upper panel), MT2 (middle panel), and GnRH (lower panel) mRNA expression in adult male rat GnRH neurons. The gels show the presence of MT1 and GnRH. MT2 expression was not detectable. "RT (-)" indicates cytosol from GnRH neurons treated without reverse transcriptase. The number on the right of each panel indicates the number of PCR cycles performed. b Expression patterns of rat MT1 and MT2 mRNAs in adult male and female rat GnRH neurons. The appearance of positive bands in the multi-cell RT-PCR experiments is shown as a percentage of the total reactions for MT1 and MT2 ( $n=47,235 \mathrm{GnRH}$ neurons for male; $n=45,225 \mathrm{GnRH}$ neurons for female). The bands for MT2 were not detectable (n.d.) in GnRH neurons. GnRH was positive in all reactions

male and female rat GnRH neurons (Fig. 7). The amount of template cDNA corresponding to two GnRH neurons was subjected to RT-PCR with specific primers for MT1 and MT2 cDNAs. For GnRH, the amount of cDNA corresponding to one cell was used. Positive bands of MT1 appeared in $10.6 \%$ of the reactions for male GnRH neurons, and $2.2 \%$ for female GnRH neurons. No positive bands of MT2 were detected. GnRH was positive in all reactions. 


\section{Discussion}

In the present study, full-length cDNAs encoding two subtypes of melatonin receptors were cloned from rat hypothalamus. The deduced proteins share high amino acid identity with other mammalian melatonin receptor counterparts, and contain motifs typical of the $G$ proteincoupled receptor family.

We mapped the cDNA sequences on the rat genome, and found that the rat MT1 and MT2 genes are comprised of two and three exons, respectively. This structure of the rat MT1 gene is homologous to that of other mammalian MT1 genes $[4,6]$. On the other hand, rat MT2 gene has an unusual structure. The last exon of MT2 gene does not contain any ORFs. In general, mRNA where the stop codon is not located on the last exon is rapidly degraded in the cytoplasm through a pathway referred to as a nonsense-mediated decay [18]. The unusual structure of rat MT2 gene is not likely to be an artifact of RACE cloning because (1) the same structure is conserved in mouse (Fig. 2, Suppl. Fig. 1A), (2) the intron boundaries of both rat and mouse MT2 genes obey the GT-AG rule, and (3) RT-PCR analysis with specific primers designed on exon 2 and 3 revealed that the transcripts are appropriately spliced (Suppl. Fig. 1B). In contrast, the human MT2 gene has a usual structure comprised of two exons, while the hamster MT2 gene lacks functional ORFs [19], suggesting that MT2 expression may be regulated in a species-specific manner.

Stable expression of rat melatonin receptor cDNAs in NIH3T3 cells showed that they have high affinities for ${ }^{125} \mathrm{I}$ Mel with mean $K_{\mathrm{d}}$ values of $73.2 \mathrm{pM}$ for rat MT1 and $73.7 \mathrm{pM}$ for rat MT2. In addition, $K_{\mathrm{i}}$ values for melatonin competition with specific ${ }^{125} \mathrm{I}$-Mel binding are characteristic of a high affinity melatonin receptor. The biochemical profiles of I-Mel and various melatonin analogues revealed similar profiles with other membrane melatonin receptors [5, 20-22].

RT-PCR analysis revealed that both rat melatonin receptor mRNAs are expressed in a wide variety of tissues although they have their own preferential expression sites. Their wide distribution may delineate the diversity of responses to melatonin within the body.

MT2 is involved in several physiological functions. However, studies using rodents lacking functional MT2 genes [7, 19] and analyses of MT1 allelic variations in ewes [23, 24] suggest that MT1 is a predominant receptor in melatonin-regulated reproductive pathways. GnRH neurons are central regulators of the reproductive axis. Several lines of evidence suggest that melatonin regulates GnRH neuronal activity and GnRH secretion through afferent neurons modulating the GnRH neuronal system [25-27]. However, direct regulatory actions of melatonin on GnRH neurons are still unknown. Our previous study showed that melatonin directly modulates $\mathrm{GABA}_{\mathrm{A}}$ receptor currents in adult rat GnRH neurons in a sexually dimorphic manner [28]. In male GnRH neurons, melatonin augments the currents, suggesting a preferential expression of MT1, because MT1 and MT2 differentially modulate GABA $_{\mathrm{A}}$ receptor functions [29]. We found that MT1 mRNA expression in adult GnRH neurons exhibits a sexually dimorphic pattern (Fig. 7). This result is consistent with our previous findings. Furthermore, our recent analysis demonstrated that blocking $\mathrm{GnRH}$ receptor activation with the GnRH antagonist, cetrorelix, induces the expression of MT1 mRNA in immortalized GnRH-secreting neurons (GT1-7 cells). Native GnRH neurons have a functional self-stimulatory GnRH system [30]. GnRH secretion is a sexually dimorphic physiological event. Therefore, the different profiles of $\mathrm{GnRH}$ release between males and females may contribute to the sexually dimorphic pattern of MT1 expression in adult rat GnRH neurons via an autocrine GnRH pathway.

In conclusion, in this study, we have characterized several fundamental properties of both rat melatonin receptor subtypes, which may provide opportunities for further investigation of the physiological potential of melatonin, using rats as an animal model.

Acknowledgments We are grateful to the Health Science Research Resources Bank for donating NIH3T3 cells. We also thank Dr. Yuko Wada-Kiyama for helpful advice. This work was supported in part by JSPS Grants-in-Aid for Scientific Research (18590070, 18590226, 19790181) and a MEXT Grant-in-Aid for Scientific Research on Priority Area (1686210).

\section{References}

1. Reiter RJ (1991) Pineal melatonin: cell biology of its synthesis and of its physiological interactions. Endocr Rev 12:151-180

2. von Gall C, Stehle JH, Weaver DR (2002) Mammalian melatonin receptors: molecular biology and signal transduction. Cell Tissue Res 309:151-162

3. Witt-Enderby PA, Bennett J, Jarzynka MJ, Firestine S, Melan MA (2003) Melatonin receptors and their regulation: biochemical and structural mechanisms. Life Sci 72:2183-2198

4. Reppert SM, Weaver DR, Ebisawa T (1994) Cloning and characterization of a mammalian melatonin receptor that mediates reproductive and circadian responses. Neuron 13:1177-1185

5. Reppert SM, Godson C, Mahle CD, Weaver DR, Slaugenhaupt SA, Gusella JF (1995) Molecular characterization of a second melatonin receptor expressed in human retina and brain: the $\mathrm{Mel}_{1 \mathrm{~b}}$ melatonin receptor. Proc Natl Acad Sci USA 92:8734-8738

6. Roca AL, Godson C, Weaver DR, Reppert SM (1996) Structure, characterization, and expression of the gene encoding the mouse $\mathrm{Mel}_{1 \mathrm{a}}$ melatonin receptor. Endocrinology 137:3469-3477

7. Jin X, von Gall C, Pieschl RL, Gribkoff VK, Stehle JH, Reppert SM, Weaver DR (2003) Targeted disruption of the mouse Mel $_{1 \mathrm{~b}}$ melatonin receptor. Mol Cell Biol 23:1054-1060

8. Armstrong KJ, Niles LP (2002) Induction of GDNF mRNA expression by melatonin in rat C6 glioma cells. NeuroReport 13:473-475 
9. Poirel VJ, Masson-Pevet M, Pevet P, Gauer F (2002) MT1 melatonin receptor mRNA expression exhibits a circadian variation in the rat suprachiasmatic nuclei. Brain Res 946:64-71

10. Audinot V, Bonnaud A, Grandcolas L, Rodriguez M, Nagel N, Galizzi JP, Balik A, Messager S, Hazlerigg DG, Barrett P, Delagrange P, Boutin JA (2008) Molecular cloning and pharmacological characterization of rat melatonin MT1 and MT2 receptors. Biochem Pharmacol 75:2007-2019

11. Doma MK, Parker R (2007) RNA quality control in eukaryotes. Cell 131:660-668

12. Keene JD (2007) RNA regulons: coordination of post-transcriptional events. Nat Rev Genet 8:533-543

13. Mazumder B, Seshadri V, Fox PL (2003) Translational control by the 3'-UTR: the ends specify the means. Trends Biochem Sci 28:91-98

14. Kato M, Ui-Tei K, Watanabe M, Sakuma Y (2003) Characterization of voltage-gated calcium currents in gonadotropinreleasing hormone neurons tagged with green fluorescent protein in rats. Endocrinology 144:5118-5125

15. Hiraizumi Y, Nishimura I, Ishii $H$, Tanaka N, Takeshita $T$, Sakuma Y, Kato M (2008) Rat GnRH neurons exhibit large conductance voltage- and $\mathrm{Ca}^{2+}$-activated $\mathrm{K}^{+}(\mathrm{BK})$ currents and express BK channel mRNAs. J Physiol Sci 58:21-29

16. Yin C, Ishii H, Tanaka N, Sakuma Y, Kato M (2008) Activation of A-type $\gamma$-amino butyric acid receptors excites gonadotrophinreleasing hormone neurones isolated from adult rats. J Neuroendocrinol 20:566-575

17. Kent WJ (2002) BLAT-the BLAST-like alignment tool. Genome Res 12:656-664

18. Chang YF, Imam JS, Wilkinson MF (2007) The nonsense-mediated decay RNA surveillance pathway. Annu Rev Biochem 76:51-74

19. Weaver DR, Liu C, Reppert SM (1996) Nature's knockout: the $\mathrm{Mel}_{1 \mathrm{~b}}$ receptor is not necessary for reproductive and circadian responses to melatonin in Siberian hamsters. Mol Endocrinol 10:1478-1487

20. Nonno R, Pannacci M, Lucini V, Angeloni D, Fraschini F, Stankov BM (1999) Ligand efficacy and potency at recombinant human $\mathrm{MT}_{2}$ melatonin receptors: evidence for agonist activity of some $\mathrm{mt}_{1}$-antagonists. Br J Pharmacol 127:1288-1294
21. Nonno R, Lucini V, Pannacci M, Mazzucchelli C, Angeloni D, Fraschini F, Stankov BM (1998) Pharmacological characterization of the human melatonin $\mathrm{Mel}_{1 \mathrm{a}}$ receptor following stable transfection into NIH3T3 cells. Br J Pharmacol 124:485-492

22. Witt-Enderby PA, Dubocovich ML (1996) Characterization and regulation of the human $\mathrm{ML}_{1 \mathrm{~A}}$ melatonin receptor stably expressed in Chinese hamster ovary cells. Mol Pharmacol 50:166-174

23. Pelletier J, Bodin L, Hanocq E, Malpaux B, Teyssier J, Thimonier J, Chemineau P (2000) Association between expression of reproductive seasonality and alleles of the gene for $\mathrm{Mel}_{1 \mathrm{a}}$ receptor in the ewe. Biol Reprod 62:1096-1101

24. Notter DR, Cockett NE, Hadfield TS (2003) Evaluation of melatonin receptor $1 \mathrm{a}$ as a candidate gene influencing reproduction in an autumn-lambing sheep flock. J Anim Sci 81:912-917

25. Glass JD, Knotts LK (1987) A brain site for the antigonadal action of melatonin in the white-footed mouse (Peromyscus leucopus): involvement of the immunoreactive $\mathrm{GnRH}$ neuronal system. Neuroendocrinology 46:48-55

26. Revel FG, Saboureau M, Masson-Pevet M, Pevet P, Mikkelsen JD, Simonneaux V (2006) Kisspeptin mediates the photoperiodic control of reproduction in hamsters. Curr Biol 16:1730-1735

27. Lincoln GA, Maeda KI (1992) Reproductive effects of placing micro-implants of melatonin in the mediobasal hypothalamus and preoptic area in rams. J Endocrinol 132:201-215

28. Sato S, Yin C, Teramoto A, Sakuma Y, Kato M (2008) Sexually dimorphic modulation of $\mathrm{GABA}_{\mathrm{A}}$ receptor currents by melatonin in rat gonadotropin-releasing hormone neurons. J Physiol Sci $58: 317-322$

29. Wan Q, Man HY, Liu F, Braunton J, Niznik HB, Pang SF, Brown GM, Wang YT (1999) Differential modulation of GABA receptor function by $\mathrm{Mel}_{1 \mathrm{a}}$ and $\mathrm{Mel}_{1 \mathrm{~b}}$ receptors. Nat Neurosci 2:401-403

30. Krsmanovic LZ, Martinez-Fuentes AJ, Arora KK, Mores N, Navarro CE, Chen HC, Stojilkovic SS, Catt KJ (1999) Autocrine regulation of gonadotropin-releasing hormone secretion in cultured hypothalamic neurons. Endocrinology 140:1423-1431 